\title{
INGER SJØRSLEV
}

\section{DET METODISKE FORLØB Kunst og håndværk i den antropologiske proces}

På et vist tidspunkt under mit feltarbejde var jeg nået til et uigenkaldeligt dødt punkt. Alt var gået i stå. Ethvert forsøg på systematik syntes at være slået fejl. Interview af en blot nogenlunde struktureret art havde det $\mathrm{i}$ det hele taget været småt med, på det seneste havde der ingen været overhovedet, og der var ikke udsigt til, at det skulle blive bedre. Min egen rolle var uklar, ikke blot som det sig hør og bør ,,midt imellem“ som både deltager og observant, jeg var usynlig, umulig i min egen selvoplevelse, pinlig i de andres øjne, min position, adfærd og beskæftigelse på stedet var i allerhøjeste grad diffus, og følelsen heraf var ikke behagelig. Den var så belastende, at hvis den havde varet meget længere end den gjorde, er der stor sandsynlighed for, at jeg var blevet syg.

Det skete imidlertid ikke. Gennembruddet kom en nat, jeg var ude at danse. Efter nogle timers indlæring af åndernes dans en aften i regnvejr i en barracão hos den åndemoder, jeg havde det mest belastede forhold til, var jeg igennem det. Ikke sådan at forstå, at resten af feltarbejdet forløb smertefrit, ej heller sådan, at jeg selv og de andre derefter var sikre på min rolle og position, men noget afgørende var der sket. Hvad der herefter viste sig af vanskeligheder var til at have med at gøre. Der kom ikke flere oplevelser af håbløshed og totalstop.

At denne nats dans var en afgørende begivenhed i mit feltarbejdes metodiske forløb, blev jeg imidlertid først klar over langt senere, da jeg sad og arbejdede med det indsamlede stof med henblik på at analysere og offentliggøre det. Og det skal være denne artikels hovedpointe, at det metodiske forløb må ses i sin helhed - ikke blot som det, der foregår under indsamlingen af data, men som en proces, der først slutter, når analysen og den tekstlige formgivning af stoffet er fuldendt. Først da står det klart, hvad der var „data“.

Når jeg tager en personlig oplevelse som udgangspunkt for overvejelser over det metodiske forløb, skyldes det, at et personligt udgangspunkt bedre bidrager til en analyse af den egentlige forskningsproces end en idealiseret videnskabeliggjort præsentation (Okeley \& Callaway 1992). Men eksemplet belyser også en anden pointe, som vedrører kropsligheden i erkendelsen. Man kunne have karakteriseret det, der sker, ved hjælp af det moderigtige antropologiske begreb embodiment, men der er snarere tale om en intellektuel forløsning, som sker via en kropslig involvering. Dette aspekt af deltagelse er ikke blevet behandlet eksplicit i den klassiske antropologi, men det ligger implicit i megen etnografisk redegørelse for deltagerobservations særlige kvaliteter. 
Præsentationen af mine personlige erfaringer skal ikke på nogen måde læses som et forsøg på at fremstille den antropologiske metode. Mit feltarbejde har været usædvanligt på flere måder, og jeg ønsker ikke at argumentere for, at en højere grad af systematik, end jeg har kunnet præstere, er umulig, ej heller, at de forhold omkring metode, jeg her omtaler, er de eneste eller vigtigste. Ikke to arbejdsprocesser er ens. Men i de allerfleste kvalitative forskningsforløb er der elementer af det, jeg her vil ind på, hvilket jeg blandt andet har kunnet konstatere, når folk fra andre fag har kunnet nikke genkendende til nogle af mine erfaringer.

Kunstnerisk frembringelse er i en vis udstrækning analog til den del af det metodiske forløb, som rummer skriveprocessen i særdeleshed og formgivningen af stoffet $\mathrm{i}$ almindelighed. Der er desuden en hel del håndværk i den form for metode, jeg her taler om: i den ganske bogstavelige forstand, at noget netop skal igennem hånden (kroppen) for at blive til et færdigformet produkt, men også i den bredere forstand, Bateson (1972) er inde på med begrebet skill (færdighed, behændighed). At opnå en følelse af flow (Bloch 1994) i en helhed af teknik og udtryk kan opleves som en gunstbevisning af nåde og ynde (grace).

\section{Metoden og genstanden}

Før jeg vender tilbage til pointerne, skal jeg fortælle lidt nærmere om objektet for mit feltarbejde. Der er nemlig endnu et forhold, der må redegøres for, og uden hvilket argumentationen ikke kan føres igennem. Det handler om erkendelse.

Igennem mange år har jeg i længere og kortere perioder studeret besættelsesfænomenet, som det indgår i de moderne brasilianske religioner candomblé og umbanda. Den metode, jeg har benyttet mig af, har været en grad af deltagerobservation, dog ikke således at jeg selv gik ind i kulten som fuldt indviet og lærte at være besat. Under analysen af, hvad besættelsesfænomenet indebærer, og under arbejdet med at fremstille stoffet blev jeg ført frem mod en analogi mellem det at befæste sit forhold til en ånd eller en gud igennem deltagelse $\mathrm{i}$ en besættelseskult og det at gennemføre en analyse og formgive et stof. Det skal jeg forklare nærmere for at anskueliggøre, hvordan genstanden for arbejdet præger og påvirker metoden. Objektet og metoden indgår i et gensidigt afhængighedsforhold og synes undertiden kun vanskeligt at kunne adskilles. For at illustrere dette er det nødvendigt at gå vejen omkring en pointe vedrørende selve besættelsesfænomenet (se også Sjørslev 1995 for et mere direkte argument).

En amerikansk kollega, Janice Boddy, har i forbindelse med studiet af zar-kulten i Sudan, som også er en besættelseskult, fået den tanke, at der er et slægtskab mellem det at være etnograf i felten og det at være besat. Kulturen lægger sig åben for eftertanke i zar-ceremonierne (Boddy 1989:356), og de ånder, der er på spil her, kommer, som ånder i Afrika gør det flest, udefra. Der er klart noget ,,andethed“ på spil her. Ånderne er fremmede, de repræsenterer det globale, nationalsamfundet, andre etniske grupper og gæster i samfundet, herunder også etnografen selv. Der er noget etnografi over det, når kvinderne i zar portrætterer fremmede og folk fra nabosamfund gennem deres ånder. Den refleksivitet, der ligger heri, ligner etnografens brug af andre kulturer til at tale om sin egen. Derfor mener Boddy, at der er en analogi mellem den etnografiske virksomhed og zar. Både besættelse og udførelse af feltarbejde er deltagervirksomhed, og ved at se verden 
gennem åndernes øjne opnår de besatte og deres omgivelser det samme, som feltarbejderen opnår ved at leve blandt dem - nemlig en gensidig forståelse af verden gennem de andres øjne. Boddy identificerer såvel feltarbejde som besættelse som former for æstetisk perception, idet begge dele har at gøre med at lære sig selv at kende gennem den anden og med at formidle det, der sker, gennem en æstetisk form.

En anden forsker, der har beskæftiget sig med besættelsesfænomenet, mener, at det karakteristiske ved indvielsen til en besættelseskult netop er, at den ånd, mediet besættes af, skifter fra at være noget diffust og vedvarende indre til noget afgrænset og temporært $y d r e$. Indvielsen til en bestemt gud eller ånd indebærer en proces fra diffusitet og formløshed til formgivet og afgrænset, fra indre til ydre (Zempleni 1987). Også der, hvor jeg har været i lære, i candomblé i Brasilien, foregår der en artikulation af diffuse indre følelser ved hjælp af de kollektive symboler og faste kulturelle udtryk, der indgår som elementer i indvielsesprocessen. Diffuse indre følelser kan forårsage sygdom, og helbredelsen finder sted dér, hvor den individuelle affekt og erindring kan finde ind i den fælles fortællings diskurs. I candomblé sker det med guden, orixáen, som markering af det både individuelle og kollektivt accepterede symbol. At være knyttet til, at være medium for, en bestemt orixá, er en måde at være personlig på, som alle kan forstå. At finde sin orixá og markere den socialt er at gøre sin subjektivitet kulturelt tilgængelig og dermed socialt acceptabel. Så når en person bliver indviet til en besættelseskult og således befæster og offentliggør sit forhold til en bestemt ånd, er der tale om en kulturel og ritualiseret italesættelse af ubevidste subjektive kræfter.

Besættelsen foregår i en rituel kontekst. I candomblés ritual er det via gudernes mytiske dramaer, og ved at den besatte, der er indviet til denne rolle, påtager sig sin skæbne i form af den odu (mytologisk skæbnefortælling), hun eller han er født med, og som viser hvem, hendes eller hans hoved - det kropslige symbol på den kosmologiske identitet hører til. Ved at tage sin skæbne på sig helbredes man. Man tæmmer sine indre ustyrlige kræfter, der viser sig ved en diffus ånd, ved at identificere den og give den navn. Man tager sin skæbne på sig i ganske bogstavelig forstand ved at gøre sig til redskab for skæbneguderne.

Besættelse er traditionelt blevet sat i sammenhæn med religion og - i socialantropologien - med social protest (Lewis 1971), men hidtil aldrig med kunst. Det vil jeg imidlertid gøre her med det formål at sammenligne erkendelsesmetoden i besættelsesfænomenet med erkendelsesmetoden i den antropologiske analyse og fremstillingsform.

At blive besat er en fremstilling og en formgivning i kulturelt accepterede fælles symboler. Der skabes en afstand, en efterligning, og herigennem en genkendelse, der gør, at noget bliver fælles. I besættelsen er det subjektivitetens fremvisning i det offentlige rum, der er tale om, og det, jeg er ude efter, er netop kombinationen af subjektivitetens offentliggørelse og det at udpege noget ud fra en fælles erfaring. I den forstand er den besattes rolle ikke ulig kunstnerens.

Det må naturligvis understreges, at det at bedrive etnografi ikke er kunst $\mathrm{i}$ den forstand, at det skulle have ,,som om“-karakter. Etnografi er ikke fiktion. ${ }^{1}$ Men ligesom besættelse udpeger noget af virkeligheden ved sin ,som om“-karakter, så udpeger etnografien også gennem sin formgivning en del af virkeligheden - en verden, der ofte ved sin anderledeshed viser ud over den kendte. Hermed kan etnografien undertiden få samme effekt som kunst, der er relativt absolut. Kunst „løfter i et kort øjeblik én, ikke $u d$ af livet, men $o p$ midt i tilværelsen. Hvorpå man falder ned igen med et brag“ med Søren 
Ulrik Thomsens ord (i Knudsen 1994). I de besættelsesritualer, hvor orixáen kommer til stede, kan man netop have denne fornemmelse af, at man bliver løftet op midt i tilværelsen, at man får lejlighed til at se sin eksistens lige i synet. De, der påtager sig at levere denne oplevelse, er dem, der tager imod guderne, de besatte, og det er blandt andet derfor, jeg har fået den tanke at hævde, at besættelsen, som i antropologien oftest er blevet kædet sammen med religion, ligesåvel kan kædes sammen med kunst. I besættelsen er det desuden ikke den, der refereres til - den bagvedliggende gud eller ånd - i en eller anden kosmologisk, religiøs betydning, der er det afgørende, men nok så meget selve den form for udtryk, besættelsen er.

\section{Fremstillingsmetoden}

Metode må i bred forstand forstås som en dialektisk proces, hvori antagelser, dataudskillelse og opdagelsers tilbagevirkning på systematikken, spørgsmålene og indsamlingsmetoden må ses i et helhedsperspektiv. Et aspekt - og det der oftest fokuseres på - er metoden i felten. Et andet er fremstillingsmetoden, den bearbejdning til præsentation af resultater og proces, der sker sidenhen. Dette aspekt er sjældent blevet problematiseret. Det er nemlig ikke repræsentationsproblematikken, som jo har været rigeligt omtalt, jeg sigter til. Det drejer sig ikke om forholdet mellem teksten og virkeligheden, men derimod om arbejdsmetoden, erkendelsesmetoden i den formgivningsproces, det er at skrive. Metoden slutter på ingen måde i det øjeblik, man forlader felten.

Jeg skal illustrere dette forhold ved at berette lidt om, hvordan bearbejdningen af mit feltmateriale helt konkret er forløbet. Det har for det første strakt sig over lang tid. Der har været lange perioder efter feltarbejdets afslutning, hvor jeg ikke har arbejdet direkte med stoffet, men hvor det har levet i underbevidstheden. I de perioder er der sket noget, som har påvirket den måde, jeg så på stoffet på, når jeg tog det frem igen. For det andet har jeg kun kunnet udskille det væsentlige - de episoder der skulle vise sig at være signifikante for analysen - ved at have et stort materiale at vælge ud iblandt. Dette materiale er kommet i stand ved en gennemskrivning, hvilket vil sige ved en teksts forholdsvis mekaniske tur gennem kroppen - i og med at jeg slet og ret, da jeg endelig følte mig klar til det, tog mine håndskrevne notesbøger og skrev lange udvalgte dele af dem rent på en computer. Det blev en proces, jeg ikke mener kunne have været erstattet af blot gennemlæsning af noterne, og hvis gunstige effekt, jeg ikke havde opnået, hvis en anden havde skrevet dem rent for mig. Den nærhed til stoffet, der kom i stand gennem den taktile følelse af ordene, der løb gennem fingrene, ned i tangenterne og ind på skærmen, kunne ikke have været erstattet af noget andet, og den var forudsætningen for, at det lykkedes mig at se en form i stoffet - en form, der var understøttet af analyse.

Ud af en tekstmængde på næsten tusind sider fik jeg således skåret en ,form“ af et langt mindre omfang. Det kunne synes omsonst med de omkring sekshundrede sider, der endte med at blive klippet fra, men de var nødvendige, for at formen kunne blive det, den blev. Ofte har jeg for mig selv tænkt, at det lignede en billedhuggers arbejdsproces. Ud af en stor „,klods“ blev der skåret en figur. Men (tekst)klodsen måtte produceres først. Erkendelsesprocessen er indlejret i formgivningen af stoffet, og i processen ligger der en kropsliggørelse. Almindeligvis skelner man mellem kropslige erkendelsesudtryk, såsom trancer og besættelser og andre rituelle fænomener som dans og musik, og en mere intel- 
lektuel erkendelsesformning gennem tekst. Heller ikke jeg mener, at der er tale om samme form. En erkendelsesformgivning gennem sproget er noget andet end en kunstnerisk ordning i form af et kropsligt udtryk. Alligevel peger lighederne i erkendelsesprocesserne hen mod en analogi mellem besættelse og fremstilling og illustrerer derved den gensidige påvirkning mellem metode og objekt.

Erkendelsesprocessen har altså såre håndgribelige aspekter. Der er noget fysisk over det at tænke (nogle af os har for eksempel svært ved at gøre det uden at have en blyant $\mathrm{i}$ hånden). Også det implicerer en form for håndværk, ligesom metode gør det. Der er en hel del snedkerarbejde i det at få givet nogle tanker eller observationer eller erfaringer form. Det, der er tale om, er en proces fra noget indre, diffust, til noget ydre formgivet, afgrænset, på samme måde som indvielsen til besættelsesmedium er det. Når håndværksprocessen går godt, kan den ligne en flow-oplevelse, føles som en rytmisk harmoni, en overensstemmelse mellem det indre og det ydre (som blandt andet Turner har beskrevet, cf. Bloch 1994). En sådan oplevelse er et kernepunkt i trancen. Men den kan også forekomme, når der er samstemmighed mellem andre indre bevægelser og en ydre form. Når man skriver, er det sprogets form; når man er besat, er det dansens form.

Metode som kunst er andet og mere end metode som håndværk. Søren Ulrik Thomsen har, i forbindelse med indkredsning af kunstnerisk kvalitet, udtalt, at den kunstneriske form til forskel fra den håndværksmæssige producerer merbetydning. „Formen er gådefuld, for selv om den har et bestemt menneskeligt ophav, svarer den igen med en egen kølighed. Så længe den tager livtag med et ukendt stof, producerer formen i en vis forstand selv betydning“ (i Knudsen 1994). Det kan man opleve, mens man former sit stof - også selv om resultatet ikke vil kunne indlemmes under kategorien kunst. Gennem formgivningen, den sproglige behandling af et stof, produceres der en (mer)betydning, som svarer tilbage og bidrager til den videre erkendelsesproces. Dette dialektiske forhold mellem stof og tanke er et vigtigt aspekt af metoden.

Man kan sige om såvel besættelsen som en del antropologi-omend ikke al antropologi - at den ligesom en del kunst - omend ikke al kunst - ,tager livtag med et ukendt stof ". I besættelsen er det det kollektivt ubevidste; det, der i fælles kosmologisk forstand er hinsides. I antropologisk forstand er det - i hvert fald en gang imellem - den radikale anderledeshed. Som antropologer ser vi nødigt os selv som gentagere af det samme (faglige, akademiske) ritual. Hellere ser vi os selv som erobrere af nyt erkendelsesland.

Er det at skrive (antropologi) så kunst? Er den antropologiske metode virkelig at ligne ved den kunstneriske? Der er uden tvivl langt flere forskelle end ligheder. Den gængse antropologiske metode rummer såvist mere håndværk end kunst. Kun sjældent slås der rigtige saltomortaler i den betydning, Søren Ulrik Thomsen tænkte på i sin omtale ikke bare af kunst, men også af kvalitet: „Man kan sige, at kunstneren fortaber sin håndværksmæssige kunnen i takt med, at han indvinder den, for i det øjeblik, han behersker en bestemt form, har han samtidig udtømt det stof, netop denne form kunne fange, og et nyt stof kræver en ny form. I kunsten er håndværket det vigtigste af det hele, men samtidig det mindste. Håndværket er hundredmetervippen, men ikke saltomortalen selv" (i Knudsen 1994). ${ }^{2}$

\section{Metoden som proces}

Hvori ligger da analogien mellem besættelse og det at bedrive antropologi? Der er noget 
med deltagerobservation, som har at gøre med, at ordentlig erkendelse må en tur igennem kroppen. Derfor er der også megen subjektivitet i det at forme sine resultater - der indgår både intellektuelle og emotionelle processer, ligesom der gør i felten, som blandt andet Rosaldo har vist det med sin fremstilling af, hvordan han hos ilongoterne lærte noget om sammenhængen mellem vrede og sorg hos ilongot gennem sine egne følelser (Rosaldo 1984).

En stor del af min erkendelse af, hvad den symbolisering, der ligger i indvielsen og oplæringen til åndedatter eller -søn i candomblé, indebærer, er kommet i takt med, at jeg har skullet formgive mit materiale, ligesom identifikationen af signifikante data er sket under den formmæssige bearbejdning. Det metodiske forløb har først udkrystalliseret sig under den analytiske del af arbejdsprocessen, i skrivefasen. Det ville have været meningsløst at se isoleret på metode i forbindelse med dataindsamlingen i feltarbejdsfasen. Som det må være et mål så vidt muligt at integrere metode i repræsentation, er det umuligt at adskille metode, dataindsamling og ,afrapportering“. Denne indsigt betyder dog ikke, at en bevidsthed om metode først er vigtig, når man når afrapporteringsfasen. Selv om et metodisk forsøg slår fejl, således som det skete under mit feltarbejde, hvor det blev klart, at data måtte indsamles gennem vedvarende tilstedeværelse og overværelse af aktiviteter, der i vidt omfang var kropslige, er det alligevel vigtigt at være bevidst om metoden - både den metode, man tilsyneladende ingen vegne kommer med, og den, man ender med at kunne identificere. De erkendelser, der kom via kropslige erfaringer, udgør ikke hele historien i mit feltarbejde. Der var andre data, der blev indhentet via interview, skrifter, almindelige samtaler, sladder og skænderier. I fremstillingen af resultatet af feltarbejdet (cf. Sjørslev 1995) har jeg indbygget en beskrivelse af det metodiske forløb, men pointen er stadig, at dette forløb først stod mig klart, da bearbejdningen af stoffet var vidt fremskreden. Først da, gennem formgivningen, forstod jeg hvilke af de begivenheder, jeg overværede under mit feltarbejde, der var betydningsfulde, og hvilke, der ikke var det.

At få skabt en form på sit stof er hårdt arbejde, som indebærer en form for metode, jeg har foretrukket at kalde et håndværk. Til gengæld giver formen undertiden noget tilbage, man ikke havde bedt om, og måske ikke engang vidste, man gerne ville have.

Formen siger noget ud over den umiddelbare gengivelse - hvis der altså er tale om kunst. Men antropologi er ikke kunst, det er videnskab. Institutionelt klassificeres det som sådan, og man benytter sig i antropologien af videnskabeligt etablerede størrelser, en fælles begrebsramme, en tradition med regler og begrænsninger. Alt dette er del af håndværket. Men derfor kan man godt under forløbet have oplevelser af den slags, der normalt forbindes med kunst. Det subjektive formes - når der er tale om fremstillingen af antropologisk viden - i begreber, der ikke bare er kulturelt, men også institutionelt accepterede, og heri ligger der også en del mode og faglige trends. Embodiment er på mode for tiden, ligesom for eksempel kulturel kreativitet. Produktionsmåder er derimod ikke moderne lige nu. Man skal ikke være blind for, at antropologisk metode er underlagt modestrømninger og tendenser, og at den enkeltes arbejdsmetode præges af, hvad der er oppe i tiden. Den akademiske verden er en institution ligesom en hvilken som helst anden, og vi forholder os i vort arbejde ikke bare til virkeligheden derude, vi forholder os nok så meget til vore kolleger og traditioner og karrierer. Bevidstheden om, hvordan den institutionaliserede del af ens fag spiller ind i de produkter, man skaber, er en form for metodebevidsthed, der er nødvendig for at skærpe den håndværksmæssige kunnen. Er man 
heldig og flittig, kan man måske komme til at beherske den, så man opnår glimtvise oplevelser af det, der er i familie med kunst, nemlig formens flow.

\section{Noter}

1. Min hensigt har på ingen måde heller været at antyde nogen fiktion i den etnografiske tekst. I modsætning til antropologiens repræsentationsdebat, vil jeg understrege, at der er afgørende forskel på at bedrive videnskab og at skrive fiktion - uanset erkendelsen af objektiviteten som et i sidste instans uopnåeligt ideal og subjektivitetens allestedsnærværende indvirken på datafremstilling.

2. Måske skulle man overveje, om det ikke er nødvendigt at finde stadig nye former til den type materiale, etnografi i den gode gammeldags betydning af beskrivelse af et (fremmed) folk kræver. Jeg har imidlertid først og fremmest brugt analogien i den hensigt at opfordre til, at man ser nærmere på den metodiske dimension i bearbejdning af et etnografisk materiale, ud fra et ønske om at opnå en bedre forståelse af de erkendelsesprocesser, der ligger heri.

\section{Litteratur}

Bateson, Gregory

1972 Style, Grace, and Information in Primitive Art. I: Steps to an Ecology of Mind. Toronto.

Bloch, Charlotte

1994 Er flow moderne? I: Allan Madsen, Signe Ejersbo og Søren Damkjær (red.): Den

kultursociologiske omtanke. København: Akademisk Forlag.

Boddy, Janice

1989 Wombs and Alien Spirits. Madison: University of Wisconsin Press.

Knudsen, Per Øvig

1994 Interview med Søren Ulrik Thomsen. Information, 7.-8. maj.

Lewis, I.

1971 Ecstatic Religion. An Anthropological Study of Spirit Possession and Shamanism.

Harmondsworth.

Okely, Judith \& Helen Callaway

1992 Introduction. I: J. Okely \& H. Callaway (eds.): Anthropology and Autobiography.

ASA Monograph 29. London.

Rosaldo, Renato

1984 Grief and a Headhunter's Rage: On the Cultural Force of Emotions. I: Y. Plattner (ed.): Text, Play, and Story: The Construction and Reconstruction of Self and Society. 1983 Proceedings of The American Ethnological Society. Washington DC.

Sjørslev, Inger

1995 Gudernes rum. En beretning om ritualer og tro i Brasilien. København: Gyldendal.

Zempléni, Andras

1987 Des êtres sacrificiels. I: Michel Cartry (red.): Sous le masque de l'animal. Essais sur le sacrifice en Afrique noire. Paris. 
